\title{
Sense of Place: A Humanistic Geographical Approach to the Themes of Place, Memory and Displacement in Bob Dylan's Songs
}

\author{
Ujjwal Kr. Panda \\ Assistant Professor, Government General Degree College, Dantan-II, Paschim Medinipur, \\ West Bengal, India. Email: biju.ujjwal@gmail.com
}

Received February 19, 2017; Revised on June 5, Accepted June 10, 2017; Published June 15, 2017.

\begin{abstract}
The paper attempts to examine the themes of place, memory, displacement and placelessness in the lyrics of Bob Dylan from the point of view of postmodern humanistic geography. The term, sense of place, has been central to the understanding of the role of a place in the formation of the identity of people living in it in the sphere of humanistic geography. According to Yi-Fu Tuan, the Chinese-American humanistic geographer, place is more than a mere cartographical location as it lives in the experience and consciousness of people who render meaning to it. Dylan's works are deeply rooted in various places he experienced in his life. His early displacement from a rural/semi-urban primary landscape and his passage to the big city of New York (secondary landscape) had given birth into him a kind of negative sense of place where there is "no direction home". In the rapidly changing socio-political milieu of the sixties Dylan remains always an outsider with his incessant search for home.
\end{abstract}

Keywords: humanistic geography, place, memory, displacement, placelessness

In recent times literary criticism has started to exhibit an increasing tendency to spatialize "the historical narrative, to attach to durée enduring critical geography" (Soja, 1989, p. 1). That a place or a territory is more than a cartographical dot on the map having been a construct of complex socio-cultural discourses with its people remains the thrust area in the works of modern humanistic geographers like Yi-Fu Tuan and Edward Relph. The term "sense of place" is the outcome of all those complexities which situate geographically as well as culturally located human beings. The connotations of sense of place can be multilayered and full of dichotomous vibes because of the essential role assigned to a place by the humanist geographers in the formation of identity of people inhabiting it. Some humanist geographers relate it to a set of typical characteristics which some geographical locations display and some do not, while to some others the sense of place is not essentially a set of extraneous territorial specialities being rather a feeling or perception of a place held by the inhabitants of the place itself. From this point of view the sense of a particular place can be different to two individuals given the context of their respective subject-positions, ethnic, social, political and cultural backgrounds etc. Actually the sense of place has now turned into an interdisciplinary buzzword and the humanistic geographical emphasis on human construction of place can be found in other disciplines like anthropology, environmental psychology, landscape architecture etc. In the present paper I would like to locate Bob Dylan's poetics in the context of this sense of place because his lyrics are almost littered with references to different places and human memories associated with those places. The

(c) AesthetixMS 2016. This Open Access article is published under a Creative Commons Attribution Non-Commercial 4.0 International License (http://creativecommons.org/licenses/by-nc/4.o/), which permits non-commercial re-use, distribution, and reproduction in any medium, provided the original work is properly cited. For citation use the DOI. For commercial re-use, contact editor@rupkatha.com 
interpretation of Dylan's works as a spatially symbolic act can be made possible quite pertinently if it is given a humanistic geographical point of view.

But before going forward with a discussion of Dylan's poetics of place we must have a primary idea about how this sense of place does operate. Yi-Fu Tuan(1991, p. 687), the renowned Chinese-American humanistic geographer, who popularized the concept of sense of place in his seminal book, Space and Place: The Perspective of Experience (1977), thinks that there may be no existence of place outside the consciousness of geographers "who, by their eloquence, are able to create place". This is true to a certain individual also who can form, quite unintentionally, the sense of a place into his own consciousness. D. E. Cosgrove in Social Formation and Symbolic Landscape (1984) situates humanistic geography in the context of a complex social formation where the cultural landscape is set against the multilayered and overlapping aspects of social differentiation. Consequently the cultural landscape becomes a symbolic act of identity formation - an allegory to be given vent in multifocal and multicultural texts. As an individual is always subject to his national and ethnic identity, the individual rendition of place becomes symbolic responses to social inclusion and exclusion. As Tuan(1976, p. 266) in his essay, "Humanistic Geography" asserts, humanistic geography seeks to achieve "an understanding of the human world by studying people's relation with nature, their geographical behaviour as well as their feelings and ideas in regard to space and place". But it is also important to know how these "feelings and ideas in regard to space and place" develop in the mind of an individual. Humanist Geographers and social psychologists consider the development of a sense of place to be the product of a number of decisive factors like comparisons between places, learning from elders, observing natural and social disasters etc. The environmental psychologists R. D. Bixler, M. F. Floyd and W. E. Hammit(2002, p.795) in their article, "Environmental Socialization: Quantitative Tests of the Childhood Play Hypothesis" have qualified "links between exposure to natural environments in childhood and environmental preferences later in life". A child learns about his surroundings by direct encounter with it through playing as well as through different roleplayings in family, culture and community. This special bond between children and childhood landscape is called "primary landscape" by humanistic geographers. This primary landscape forms people's identity and becomes a reference point of comparison and contrast for considering subsequent places (or "secondary landscape") in later life. The child grows up and the grown-up man begins to consider new places in relation to this primary landscape experienced during childhood. So, displacement plays a vital role in the making of a person's sense of place. Placeexperiences, memory and displacement remain a constant trope in Bob Dylan's poetics. In this paper there is an attempt to reexamine his works from the point of view of humanistic geography to show how his lyrics are centered around a distinct sense of place which emanates from a sense of being displaced and being nowhere with "no direction home". The paper also attempts to seek the factors responsible for this sense of place in relation to his life and early career as a performer and tries to show the possible ways he followed to cope with this sense of unbelonging. In this context I have mainly made use of his songs of the 1960s and also have referred to two of his later albums, Love and Theft (2001) and Modern Times (2006) to show the unmistakable continuity of this themes in his work. At the same time, Dylan's autobiography, Chronicles-Volume One (2004) has been instrumental in consolidating these findings to a large extent.

Actually the advent of Bob Dylan in the musical scene of the United States in the early 1960 coincided with the immense sociopolitical upheaval of the time. It was the famous "swinging sixties" when there was a tendency to break free from the fetters and inhibitions of an old world. The changes were most vehemently felt in the cultural front- in the revival of folk 
tradition, in the Rock n' Roll and, obviously, in the fatal art of the Beat-generation writers. In the words of Dylan himself -

I was born in the spring of 1941. The Second World War was already raging in Europe, and America would soon be in it. The world was being blown apart and chaos was already driving its fist into the face of all new visitors. If you were born around this time and were living and alive, you could feel the old world go and the new one beginning. It was like putting the clock back when B. C. became A. D. Everybody born around my time was a part of both. (2004, 28)

Born as Robert Allen Zimmerman in an American Jewish family in a small town (Duluth) of Minnesota and grown up in the mining town of Hibbing, Dylan came to the big city of New York in 1961 with the intention of performing there and to meet his musical idol Woody Guthrie. This passage from the rural/semi-urban primary landscape to an urban secondary landscape was a kind of early transcendence of belonging to young Dylan. To quote Dylan from Chronicles -

I'd seen and heard trains from my earliest childhood days and the sight and sound of them always made me feel secure. The big boxcars, the iron ore cars, freight cars, passenger trains, Pullman cars. ... The sound of trains off in the distance more or less made me feel at home, like nothing was missing, like I was at some level place, never in any significant danger and that everything was fitting together. (2004, 31)

Surely Dylan had not left his country but he is here expressing the typical crisis of an individual living in a migrational city. Richard Elliot in his essay, "The Same Distant Places: Bob Dylan's Poetics of Place and Displacement"(2009) has referred to this early psycho-biographical crisis. Many theorists who have concentrated upon the relationship of place and memory has pinpointed city as a hinterland for witnessing the layering of history and archaeological explorations of collective cultural memory. The constant and unavoidable changes of landscape that a city stands for provide it a liquid identity in the context of postmodernism. In the words of Mark C. Taylor -

In the city, place is transformed into space of anonymous flows. As technologies change first from steam and electricity and then to information, currents shift, but patterns tend to remain the same. Mobility, fluidity and speed intersect to effect repeated isplacements in which everything becomes ephemeral, nothing remains solid or stable.(2002, 19)

In the American popular music of the twentieth century this image of an urban vagabond looms large. It is almost everywhere from midnight blues to the dustbowl ballads of Woody Guthrie or the spiritual numbers like "This world Is Not My Home" and "I Don't Want to Get Adjusted". The dispersion from the known landscape, the changing milieu of a rapidly changing city and the widespread anti-establishment thoughts of the American artists perhaps gave birth into the mind of young Dylan a kind of nowhereness. But at least towards the beginning of his career he remained faithful to his folk root which itself is an expression of displacement. Undoubtedly popular music is a sound of the city not only because its obvious veracity to a metropolitan experience; even music coming from non-metropolitan roots(like country or folk) needs a city for its production, recording, performance and broadcasting. From this point of view music and place are almost inseparable. As George Lipsitz writes -

Through music we learn about place and displacement. Laments for lost places and narratives of exile and return often inform, inspire, and incite the production of popular music. Songs build engagement among audiences at least in part through references that 
tap memories and hopes about particular places. Intentionally and unintentionally, musicians use lyrics, musical forms, and specific styles of performance that evoke attachment to or alienation from particular places. $(1994,4)$

Placelessness is a constant feature of Dylan's early lyrics and this may be a result of his displaced subject-position.

In Martin Scorsese's 2005-documentary on Bob Dylan, No Direction Home, the camera zooms in on the wrinkled face of an aged Dylan saying the following words -

I had ambitions to set out and find like an odyssey, going home somewhere. I set out to find this home that I'd left a while back and I could not remember exactly where it was but on my way there, and encountering what I encountered on the way was how I envisioned it all. I didn't really have any ambition at all [...] I was born very far from where I'm supposed to be and so I'm on my way home.

The idea of home, here, is intentionally blurred to give an estimate of lost primary landscape and an unsure secondary landscape. An early song, "I Was Young When I Left Home", which was recorded by Dylan as early as in 1961 but released as a bonus track with only some copies of Love and Theft (2001) refers to this placelessness very pungently -

I was young when I left home

And I been out a-ramblin' 'round

And I never wrote a letter to my home

To my home, Lord, to my home

And I never wrote a letter to my home

It was just the other day

I was bringing home my pay

When I met an old friend I used to know

Said your mother's dead and gone

Baby sister's all gone wrong

And your daddy needs you home right away

Dylan sings this song with the heavily inflected accent of a New Yorker suggestively to denote a spatial shift where a return is almost unviable. Dylan writes -

Used to tell my Ma sometimes

When I see them riding blinds

Gonna make me a home out in the wind

In the wind, Lord in the wind

Make me a home out in the wind 
I don't like it in the wind

Wanna go back home again

But I can't go home thisaway

Thisaway, Lord Lord Lord

And I can't go home thisaway

Actually, this image of a cultural outsider was a result of Dylan's being on the edge of things from the very beginning of his life. Jeff Taylor and Chad Israelson in their book, The Political World of Bob Dylan: Freedom and Justice, Power and Sin (2015) comment -

Though his career began in New York, it was neither Dylan's home nor his background.

Bob Dylan's roots lie to the north and west, in a small Minnesota mining town with an

ever smaller Jewish community. $(2015,2)$

They are also of the opinion that this marginal identity of being an "other" also formed Dylan's political consciousness which always took the side of the peripheral or the marginal although Dylan always preferred to remain elusive in this matter. Taylor and Israelson comment -

When he was six, his family moved from Duluth to Hibbing about 75 miles to the northwest. Despite having a history of radical political activity, Hibbing in the 1940s and 1950s may have seemed dreary to a youngster. Margaret Stark, who knew Dylan in high school says, "He was treated as an outcast as he was growing up. He was odd, and different." Thus, Dylan, both Jewish and socially unconventional, experienced some element of being "the other" among the dominant culture of his hometown." $(2015,2)$

In Chronicles Dylan has given vent to his childhood fear of mine-owners at Hibbing. This fear remained unabated throughout his life and his distrust of those in power or in establishment has been time and again given expression in his songs.

The songs written in the 1960 s are mainly concerned about places which are marginal and people either displaced or placeless. The famous song "Blowin' in the Wind" is reminiscent of a place that has turned into an uncertain and terrible territory -

Yes, 'n' how many ears must one man have

Before he can hear people cry?

Yes, 'n' how many deaths will it take till he knows

That too many people have died?

The answer, my friend, is blowin' in the wind

The answer is blowin' in the wind.

In the context of communist revolution, anti-war and anti-slavery movements that the 6os epitomized Dylan's lyrical expression made him an unwilling voice of the generation. In many songs of this time the characters are world-weary, clueless and resultantly peripheral like their creator himself and they are placeless being always on the way with "no direction home". In "A Hard Rain A-Gonna Fall" from The Freewheelin' Bob Dylan(1963), which has a obvious reference to the atomic rain (although Dylan has denied any such possibility), a man who has wandered the whole world in search of a suitable place to live finally gives up - 
Heard one person starve, I heard many people laughin'

Heard the song of a poet who died in the gutter

Heard the sound of a clown who cried in the alley

And it's a hard, and it's a hard, it's a hard, it's a hard

And it's a hard rain's a-gonna fall

In "Down The Highway" of the same album a displaced and wandering character comes back -

Well, I'm walkin' down the highway

With my suitcase in my hand

Yes, I'm walking down the highway

With my suitcase in my hand

Lord, I really miss my baby

She's in some far-off land.

The references to places, spaces and displacement are numerous in Bob Dylan's early songs. But as he refers to the experience and memory of place in his songs there remains a powerful sense of place despite spatial uncertainties. Certainly many songs deal with a sense of placelessness but being nowhere also implies a feeling of being everywhere. So, in "Bob Dylan's Dream" Dylan looks back to his primary landscape, his lost friends and his uprooted identity from the perspective of "a train heading west".

Displacement looms large in many songs of his 1964-album The Times they are A-Changin'. Placelessness here interfuses with the humanistic geographical concept of a negative sense of place or a "landscape of fear". In the words of Yi-Fu Tuan -

What are the landscapes of fear? They are the almost infinite manifestations of the forces of chaos, natural or human. Forces for chaos being omnipresent, human attempts to control them are also omnipresent. In a sense, every human construction- whether mental or material - is a component in a landscape of fear because it exists to contain chaos.(1979, p. 6)

In "With God On Our Side", the speaker introduces him to be a man from nowhere and describes a appalling secondary landscape torn by the memories of horrible wars -

The First World War, boys

It came and it went

The reason for fighting

I never did get

But I learned to accept it

Accept it with pride

For you don't count the dead

When God's on your side.

Towards the end the man is "weary as Hell" with the apprehension of a future war - 
So now as I'm leavin'

I'm weary as Hell

The confusion I'm feelin'

Ain't no tongue can tell

The words fill my head

And fall to the floor

If God's on our side

He'll stop the next war.

Again, in "North Country Blues" the speaker expresses fear of a landscape where he/she turned helpless when "red iron pits ran empty". Although the place has not been defined, the topographical details clearly conjure up the mining town of Hibbing, Minnesota where Dylan grew up. The unemployed speaker towards the end of the song again gives expression to human displacement -

The summer is gone

The ground's turnin' cold

The stores one by one they're a-foldin'

My children will go

As soon as they grow

Well there ain't nothing here to hold them.

Again the title of the famous album, Highway 61 Revisited, puts forth a strong sense of place in its attempt to look back at the lost primary landscape. Dylan says in Chronicles-

Highway 61, the main thoroughfare of the country blues, begins about where I came from... Duluth to be exact. I always felt like I'd started on it, always had been on it and could go anywhere from it, even down into the deep Delta country. It was the same road, full of the same contradictions, the same one-horse towns, the same spiritual ancestors. The Mississippi River, the bloodstream of the blues, also starts up from my neck of the woods. I was never too far away from it. It was my place in the universe, always felt like it was in my blood.(2004, 240-241)

The famous song from Highway 61 Revisited (1965), "Like A Rolling Stone", tends to revisit a broken personal relationship in terms of placelessness -

How does it feel

How does it feel

To be without a home

Like a complete unknown

Like a rolling stone?

Again, "Desolation Row", the long rock ballad, tends to evoke an American wasteland - a secondary landscape violently gone astray. This image of a tattered and broken secondary 
landscape becomes prominent in many songs of Bringing It All Back Home which was released in the same year. In "Mr. Tambourine Man" this spatial dilemma results into a clueless escape-wish-

Though I know that evenin's empire has returned into sand

Vanished from my hand

Left me blindly here to stand but still not sleeping

My weariness amazes me, I'm branded on my feet

I have no one to meet

And the ancient empty street's too dead for dreaming.

This disillusioned appreciation of place leads the speaker towards the end of the song to request the Tambourine Man to take him to a place "far from the twisted reach of crazy sorrow" -

Yes, to dance beneath the diamond sky with one hand waving free

Silhouetted by the sea, circled by the circus sands

With all memory and fate driven deep beneath the waves

Let me forget about today until tomorrow

Escape either from a claustrophobic society or a suffocating personal relationship is also the subject-matter of the songs "Maggie's Farm" and "It's All Over Now, Baby Blue".

Actually, displacement has been a constant theme in Bob Dylan. He always remains on the margin of spatial identity where the loss of primary landscape has never been recompensated with a more positive secondary landscape. Naturally his subject-position remains liminal or always on flow. This remains unchanged in his later works also. "Mississippi", a song included in his 2001album, Love and Theft, again gives vent to the same sense of being placeless. The singer here addresses the river of his childhood in a tone of regret-

We're all boxed in, nowhere to escape

City's just a jungle; more games to play

Trapped in the heart of it, tryin' to get away

I was raised in the country, I been workin' in the town

I been in trouble ever since I set my suitcase down

Again in "Thunder On The Mountain" from his much-acclaimed album Modern Times (2006) there is again an unfulfilled wish to go back to the primary landscape -

Gonna make a lot of money, gonna go up north

I'll plant and I'll harvest what the earth brings forth

The hammer's on the table, the pitchfork's on the shelf

For the love of God, you ought to take pity on yourself.

Dylan's sense of place, so, remains same throughout. At the same time, the bond with his primary landscape becomes stronger with the passing of time. Taylor and Israelson comments -

As Dylan advanced in his career, he became less evasive about his childhood and willingly acknowledged the impact that northern Minnesota had on him. In 1978, the only interview 
Dylan granted in the Upper Midwest was with High Times, the Hibbing High School newspaper. Prior to a concert in St. Paul, he told the paper's student editor that he was "proud to be from Hibbing". He also said that hailing from northern Minnesota "gave me a sense of simplicity".(2015, 9) To conclude, we can aptly refer to Edward Casey -

As Freud, Bachelard, and Proust all suggest, to refind place - a place we have always already been losing - we may need to return, if not in actual fact then in memory or imagination, to the very earliest places we have known. (1993. x)

\section{References}

Bixler, R. D. et al. (2002). "Environmental Socialization: Quantitative Tests of the Childhood Play Hypothesis", Environment and Behavior 34(6), pp795-818.

Casey, E. S. (1993). Getting Back into Place: Toward a Renewed Understanding of the Place-World, Bloomington and Indianapolis: Indiana University Press.

Cosgrove, D. E. (1984). Social Formation and Symbolic Landscape, Wisconsin: University of Wisconsin Press.

Dylan, B. (2004). Chronicles - Volume-1, . New York: Simon and Schuster.

- . Songs of Bob Dylan, Retrieved from http.//www.bobdylan.com/songs

Elliot, Richard. (2009). "The Same Distant Places: Bob Dylan's Poetics of Place and Displacement", Popular Music and Society 32(20), pp 249-270, pre-publication draft retrieved from https://www.academia.edu/196389/The_Same_Distant_Places_Bob_Dylans_Poetics_of_Place_and_Disp lacement

Lipsitz, G. (1994). Dangerous Crossroads: Popular Music, Postmodernism and the Poetics of Place, New York: Verso.

Soja, E. (2011). Postmodern Geographies: The Reassertion of Space in Critical Social Theory, New York: Verso.

Taylor, J. et al., (2015). The Political World of Bob Dylan: Freedom and Justice, Power and Sin, New York: Palgrave Macmillan.

Taylor, M. C. et al., (2002) Grave Matters, London: Reaktion Books.

Tuan, Y. (1977). Space and Place: The Perspective of Experience, Minneapolis: University of Minnesota Press.

- . (1976). "Humanistic Geography", Annals of the Association of American Geographers, Vol. 66, No. 2. pp. 266-276. Retrieved from http:// www.jstor.org/ stable/ 2562469? seq=1\# page_scan_tab_contents

- . (1979). The Landscape of Fear, New York: Pantheon books.

Dr. Ujjwal Kr. Panda is an Assistant Professor in the Department Of English at Government General Degree College, Dantan-II, Paschim Medinipur, West Bengal, India. 